\title{
DEVELOPMENT OF ENTREPRENEURIAL ENVIRONMENT IN SLOVAKIA
}

\author{
Viera ÖLVECKÁ \\ Faculty of Management, Comenius University, Bratislava, Slovakia \\ E-mail: viera.olvecka@fm.uniba.sk \\ doi:10.13165/IE-13-7-2-06
}

\begin{abstract}
Entrepreneurial environment in Slovakia is monitored and recently demonstrates deteriorative level. Entrepreneurs themselves defined the shortfalls as it was also confirmed by analyses of regional and national agencies. In the Slovak Republic, the small and medium enterprises have an irreplaceable role to play. Entrepreneurs consider levying charges, frequent regulation modifications, difficult exaction of justice, unavailability of loans, ambiguous policies, corrupt practices at magistracies, tax charges, and many others to be the biggest obstacles. Definition and solution of these problems is highly important to support small and medium businesses. It can foster overall conditions of entrepreneurship in Slovakia and also increase Slovakia's competitiveness.

The aim of the article is to point out entrepreneurship and business environment conditions in the Slovak Republic, mainly the organisations oriented towards small and medium enterprises, which have an irreplaceable role predominantly in the field of workplace establishment and regional development.
\end{abstract}

JEL classification: G32.

Key words: entrepreneurial environment, economy, charges, regulations, corruption, market, stability.

Reikšminiai žodžiai: entreprenerystès aplinka, ekonomika, mokesčiai, reguliavimas, korupcija, rinka, stabilumas.

\section{Introduction}

The basis for national performance is state supremacy, which is carried out through regulations. Well-formulated law, which would serve as a function of the legal framework, is exactly what is missing in Slovakia. Contra- productive and practically unrealisctic regulations are often approved; afterwards, an amendment is prepared. All this creates chaos and incoherence. The fact is that there is no excuse for the lack of -awareness of the law. Primarily, in case of self-employed and small entrepreneurs, there is another factor to be considered, namely that some of them cannot afford to hire 
pricey specialists, lawyers, consultants or the entire crisis management staff that would also monitor any changes in the legislation governing the entrepreneurial environment.

For a specific business activity, the legislation business framework is very important. According to Article 2(1) of the Commercial Code, an entrepreneurial activity is understood to be "systematic activity which is independently carried on for the purpose of making a profit by the entrepreneur in his own name, and at his own liability." (Majdúchová et. al. 2008, p. 15).

"An enterprise is a part of state microeconomics, as it is considered to be an economic subject or economic element." (Ölvecká, 2010, p. 9). Economic or business subjects proceed through diverse stages of progress throughout their existence; stability is often disturbed by national and international impact or environmental and sociological processes. Their development is determined by changes, production system or level of technology, human resources, etc.

In comparison to the so-called old Member States of the European Union, Slovakia still has relatively low performance economy and is a poor country. Therefore, for us it is more important to have a favourable entrepreneurial environment that would help us to catch up with more developed countries. From that point of view, the business environment is not only for entrepreneurs, but to a larger extent for the citizens as consumers, who will have a better living standard perspective and higher quality products and services through that.

This is where business ethics should come into practice, based on trust and responsibility. "Under the concept of ethics, we understand the applied integrative normative ethics, which is focused on the examination of interaction between ethics and economy" (Remišová, 1999, p. 35). Contemporary trends in the development of the business environment, in globalisation processes and in the efforts of business entities to become competitive give rise to a new environment characterised by identification, acquisition and maintenance of competitive advantages. The latter advantages are a decisive factor permitting companies to maintain and extend their market position. The successful company needs the successful management paying attention to positive development trends, the fulfilment of defined goals and the maximisation of the company's market value (Kajanová, 2011).

From a broader perspective, business environment reflects quality of economic conditions and entrepreneurial activity prerequisites of all participating business entities (Ministry of Foreign Affairs of the Slovak Republic, 2007). "Economic growth is represented by the production possibilities curve shifting outward as the result of an increase in resources or an advance in technology. The phrase 'new economy' refers to economic growth resulting from technological advances that make businesses and workers more productive" (Tucker, 2008, p. 46).

\section{Conditions for the Entrepreneurial Environment}

Definition of "good" or favourable entrepreneurial environment is highly significant. Various people using this term have often something completely different in mind. For some of them, the entrepreneurial environment is good, when is it prosperous towards them, their firm, and the industry they participate in. Moreover, they try to faci- 
litate it with the help of privileges, exceptions, allowances, etc. approved by the government and the parliament. It is misshaped by a selective policy of favours, which provide competitive advantage to preferred firms or industries. It detriments all the others that are disadvantaged (Klamová, 2010).

A favourable entrepreneurial environment is, consequently, an environment that creates the same beneficial conditions for all, regardless of anyone's origin, legal form, size, etc. This fundamental truth is not understood by number of politicians responsible for economy, as well as many entrepreneurs, who prefer purblind "good" environment for themselves. As long as this remains unchanged, the business environment will not cardinally improve any time soon.

Qualitative entrepreneurial environment determining the conditions for long-term sustainable economic growth is an essential anticipation of business development and competitiveness improvement of the Slovak Republic on an international scale. The main goal of the Slovak economy is to get closer to the developed economies of Europe within the shortest time possible.

Business environment in each territorial unit entails some specific features that affect not only the number of enterprises and their success, but also the level of development of the region. The enterprise and the environment in which a business entity exists are mutually influential. (Kováč, 2011, p.365)

\section{Development of Foreign Trade of the Slovak Republic.}

Monitoring the quality of entrepreneurial environment in Slovakia and certain generalisation of the observations with similar parameters in some other transitive economies points out to a fact that the following crucial areas determine business intentions and practical decisions: area of financing the entrepreneurial subjects and capital, employment, unemployment and quality of human resources, social and welfare policy in terms of functioning labour market and its legislation, overall legal framework of entrepreneurship, tax and charges policy in terms of public financing policy, range of market regulation, conditions of entering and exiting the market, anti-monopolist policy, subsidies and subventions, licensing policy, certification and system of estate property records.

Figure 1. Foreign trade of Slovakia (in billions EUR)

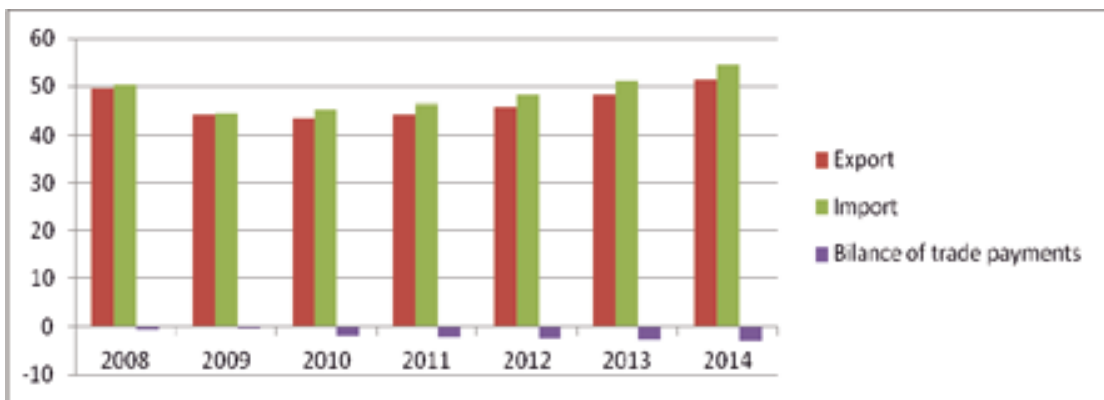

Source: Ekonomika - EuroEkonóm.ekonomika-slovenska-2014. In Euroekonom.sk. [online]. Last accessed on 04.05 .2013 at http://www.euroekonom.sk/ekonomika/ekonomika-sr/ekonomika-slovenska-2014. 
Small and medium-sized enterprises in Slovakia. According to the research of regional and national agencies that transact and process outputs in a statistical form, as well as based on the author's own research, the most serious difficulties can be assigned to the development of small and medium-sized enterprises in Slovakia, as appointed by entrepreneurs themselves (Butoracová Šindleryová, Morovská, 2009).

For companies to survive, it is "essential that management identifies potential opportunities and threats in its current environment and takes specific steps immediately, so that the organisation will not be taken by surprise by any developments that may occur in the future. In particular, the company should consider one or more of the following courses of action:

a. developing new products for sale in existing markets;

b. developing new products for new markets;

c. developing new markets for existing products." (Drury, 2009, p. 7)

Table 1. Development difficulties of small and medium-sized enterprises

\begin{tabular}{|l|c|}
\hline \multicolumn{1}{|c|}{ Difficulties during development } & expressed in \% \\
\hline - tax charges & 63 \\
\hline - frequent changes of regulation & 43 \\
\hline - difficult law justification & 27 \\
\hline - unavailability of loans & 26 \\
\hline - uncertainty of regulation & 24 \\
\hline - corruption in bureaux & 23 \\
\hline - level of tax rates & 22 \\
\hline - high interest rates & 14 \\
\hline - lack of transparency & 12 \\
\hline - inflation & 6 \\
\hline - blackmailing & 4 \\
\hline - foreign exchange rate & 2 \\
\hline - other difficulties & 8 \\
\hline
\end{tabular}

Source: compiled according to Butoracová Šindleryová, Morovská, 2009, p. 27 •

Negative evaluations of entrepreneurs mainly caused the increase of tax charges and changes in the Labour Code, which negatively affected the position of entrepreneurs as providers of employment. Slovak entrepreneurs understand the need for consolidation of public finances, but the approach through which the government transfers most of the consolidation charge onto firms and self-employed individuals will have undermining influence on the entrepreneurial environment (Podnikatel'ská aliancia Slovenska, 2012). Entrepreneurs react to tax increase very sensitively, if they are not compensated with better public services by the government and better environment that may be achieved, for example, by reducing excessive administrative burden or lay justification. Profit decrease caused by higher corporate tax will appeal demotivating in terms of economical activity of enterprises and it can also lead to a drop of investments and increase the efforts of greater optimisation of tax duties.

The business environment in Slovakia has some peculiarities in relation to specific social, political, economic and natural environment. No region, administrative or 
territorial unit has the same conditions and the cycle of mutually influencing factors. Public administration at various levels is, however, able to affect the environment, to ensure regional development while reducing social and business disparities. One of the factors determining the development of citizens, business entities and society is security. When deciding whether to set up a business, the deciding criteria are not only access to employment and services, suppliers and customers, but also the security of the site. Also, the company chooses the environment similar to the scheme. In addition to criminality or healthy environment, the level of enforcement of the law is a very important criterion (Filip, Kováč, 2011, p. 239)

Entrepreneurs in Slovakia blame the government for its insufficient efforts to decrease deficit by reducing public expenses. They noted significant decline in terms of law justification and jurisdiction functioning, effective state economy and access to state assistance, application of equality in terms of law, as well as comprehensiveness, applicability and stability of legal regulation (Podnikatelská aliancia Slovenska, 2012a).

Predominantly, according to entrepreneurs, wrongly functioning justice is one of the main difficulties on a long-term basis preventing the improvement of the entrepreneurial environment (Asociácia zamestnávatel’ských zväzov a združení, 2013). In the opinion of the entrepreneurs, information transparency of business entities has improved, including relation with the environment, addressing to business partners, management system and human resource management, the level of technologies and production quality.

Businessmen consider it unfair that the state undertakes insufficient efforts to stop the depletion and rejuvenation of social recourse exploitation, the government substitutes with too restrictive arrangements in terms of economic activity. Incapability to modernise public staff and adequately react to fast changing circumstances lead to the increased distrust towards public institutions. The list of items characterised by the largest drop during the last quarter is amended by labour legislation, waiting for changes that would worsen flexibility on the labour market. Consequently, it will lead to long-term criticised low law justification and jurisdiction functionality and inconsistent application of the principle of equality. Together with the on-going worsening credit discipline of business partners, these two areas lead to the largest barriers preventing the upturn of entrepreneurial environment.

As to the changes of the Labour Code, we can assume that their authors attempted to secure higher earnings of the Social Insurance Agency, as well as to convince the employers to employ people under permanent contracts, due to the liability for enlistment of holders of temporary contracts. The question remains whether this step will not have only zero effect on the decrease of unemployment rate, but will become a negative consequence. The authors of many studies assume that the number of temporary contracts will decrease and the unemployment rate will increase due to employers' reduction of the number of employees. Additional aspects pertain to the changes in the fields of labour unions, overtime and its reimbursement, working time, flexible working hours, breaks during work, reimbursement for the lost working time, night shifts, vacation leave, wages, reimbursement for holidays etc., which will not bring competitive advantage to the entrepreneurs as employers in Slovakia (Rentková, Rentková, 2012) 
Figure 2. Unemployment rate in the Slovak Republic

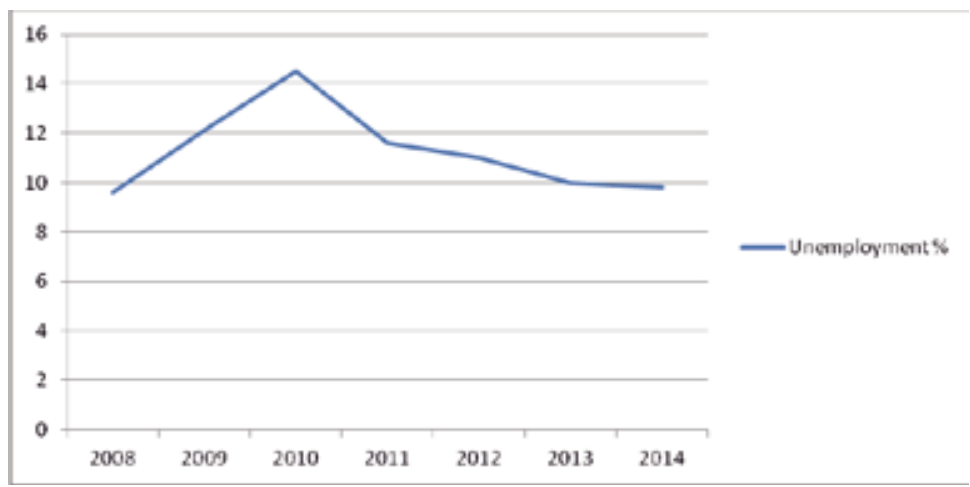

Source: Ekonomika - EuroEkonóm.eknomika-slovenska-2014. In Euroekonom.sk. [online] [accessed on 04.05.2013].

Available online: <http://www.euroekonom.sk>

Slovakia disposes of adequate labour force. In many cases, people agree to work for a wage that equals to the minimum wage. The level of minimum wage is determined by the Code of National Council of the Slovak Republic, No. 663/2007.

\begin{tabular}{|c|c|}
\hline Year & Minimum wage level in EUR \\
\hline 2007 & 268.87 \\
\hline 2008 & 268.87 \\
\hline 2009 & 295.50 \\
\hline 2010 & 307.70 \\
\hline 2011 & 317.00 \\
\hline 2012 & 327.20 \\
\hline 2013 & 337.70 \\
\hline
\end{tabular}

Figure 3. Minimum wage level in 2007-2013

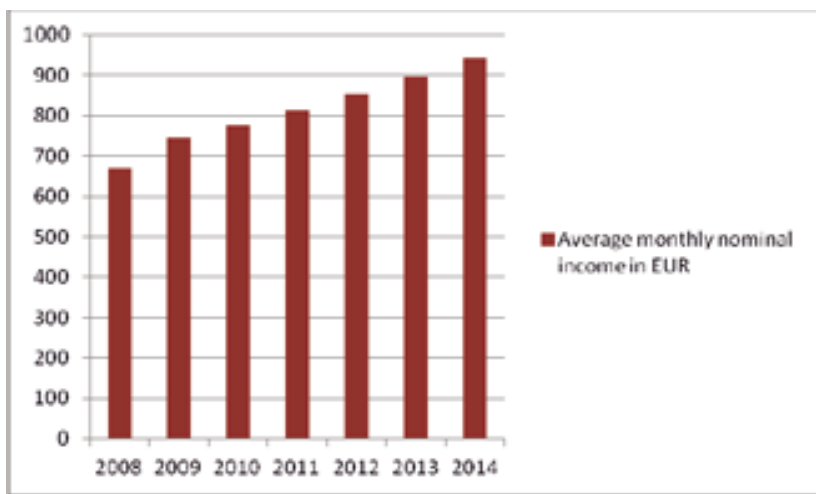

Source: compiled by the author according to the Bureau of Statistics 
Figure 4. Average monthly nominal income in Slovakia

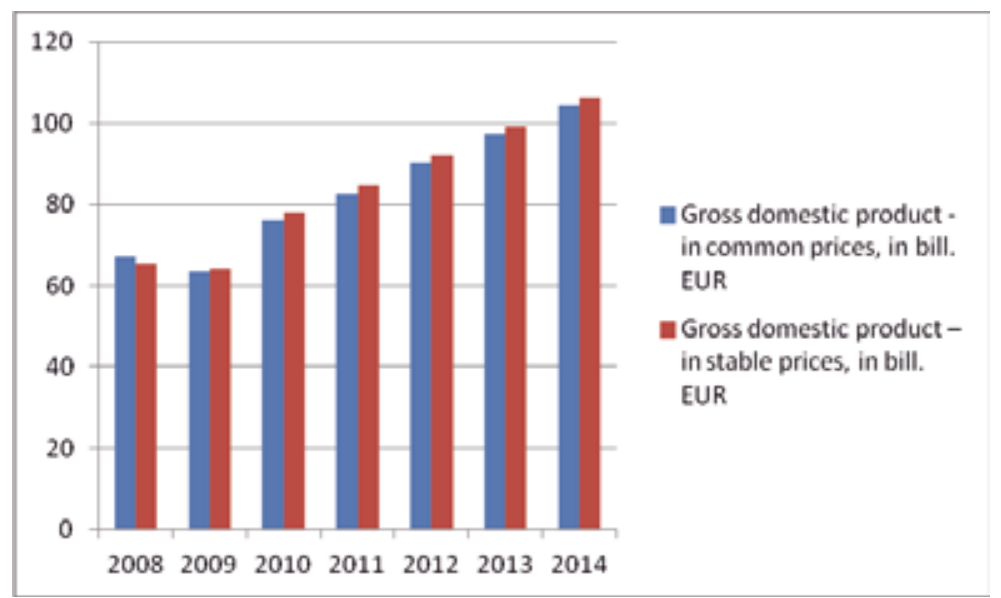

Source: Ekonomika - EuroEkonóm.eknomika-slovenska-2013. In Euroekonom.sk. [online] [accessed on 04.05.2013]. Available online: <http://www.euroekonom.sk>

\section{Requirements Towards the Upturn of the Entrepreneurial Environment}

The rise in the past monitoring noted only a minimum of items. They concern self-functioning of businesses and include informational business transparency, relation to natural environment or behaviour towards business partners. The requirements of Slovakian entrepreneurs for the general enhancement of the entrepreneurial environment are presented in the table below:

Table 2. Requirements towards the upturn of the entrepreneurial environment

\begin{tabular}{|c|l|}
\hline & \multicolumn{1}{|c|}{ Conditions for enhancing the entrepreneurial environment } \\
\hline A. & Securing the macro-economic stability and enhancement of public finance \\
\hline B. & Fighting against corruption and clientelism \\
\hline C. & Increased law justification and quality of legislation \\
\hline D. & Decrease of tax charge and effective social system \\
\hline E. & Improving the quality of education \\
\hline F. & Reformation of existing departments and public institutions \\
\hline G. & Transparency of public spending, \\
\hline H. & Defence of honest businessmen against unfair practices of business partners \\
\hline I. & Perception of entrepreneurs as partners in terms of economic development \\
\hline J. & Compliance with the obligations and regulations of the EU \\
\hline
\end{tabular}

Source: compiled according to the Podnikatel'ská aliancia Slovenska. (2012b). 


\section{A.Securing the Macro-Economic Stability and Enhancement of Public Finance}

This means managing a country responsibly and securing macro-economic stability, participation in decreasing the deficit of public finances and heading towards the formation of budget surplus, mainly by effectively increasing collection of taxes, efficient usage of public resources and implementation of the pension reform in the first pillar, no incensement and no hiding of country's debt.

During the recent years, Slovakia's debt was growing extremely fast. The deficit of public finances reached $4.6 \%$ of GDP in 2012. The debt is to reach $2.4 \%$ of GDP in 2014 and $1.9 \%$ of GDP in 2015.

High level of public debt means that for the country to eliminate its debt it will have to either increase taxes or cut some other expenses, which would result in the shortage of available consumer pensions, and consequently a decline of consumption and aggregated demand. If there is no consumption, sales decline, supply decreases, therefore the unemployment rate rises and again the wages fall; it all turns into a vicious circle. The pension and health systems greatly impact debt occurrence, but this happens not only in Slovakia, and by reason of the aging population the state needs to priorities these problems (Stoličná, 2012).

Figure 4. Gross domestic product of Slovakia

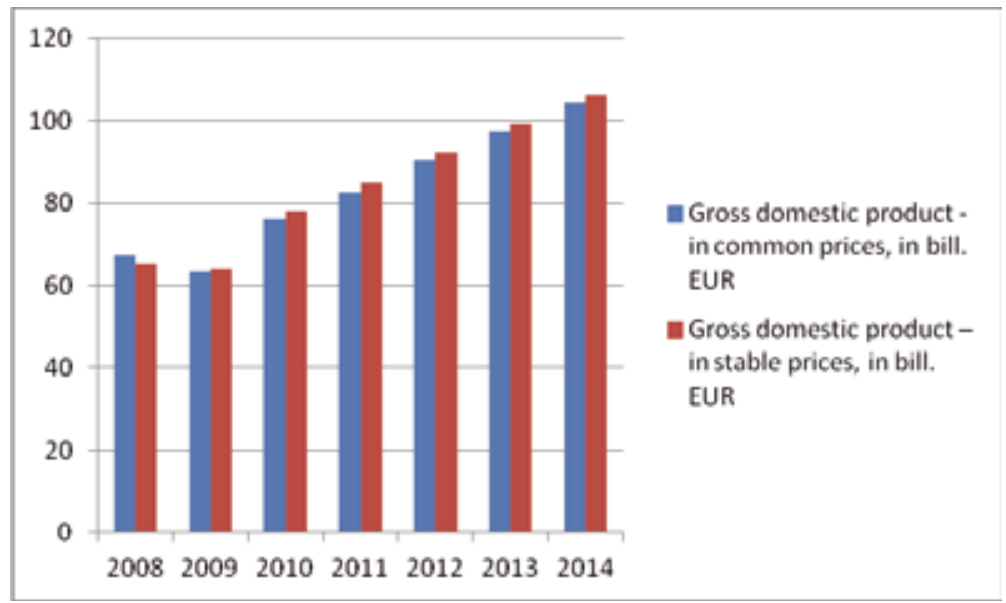

Source: Ekonomika - EuroEkonóm.eknomika-slovenska-2015. In Euroekonom.sk. [online] [accessed on 04.05.2013]. Available online: <http://www.euroekonom.sk>

At the beginning of 2012, the public debt was 5500 EUR per capita. Even though the overall level of Slovakia's public debt is still not comparable to that of the other states, Slovakia is more vulnerable than, for instance, Japan or Great Britain. In contrast to these large countries with strong domestic financial sector, Slovakia is, however, a small country with an open economy and relatively small domestic savings. 


\section{B. Fighting Against Corruption and Clientelism}

Corruption is a serious global problem. Its solution is important and requires cooperation of all parties concerned. In order to solve the corruption problem radically, the citizens need to put adequate pressure on politicians, so that they prepare anti-corruption tools, as well as the staff in the public sector to apply those tools. However, getting engaged - reacting on the matters coming from the politicians and the media - primarily means to be informed.

Cautious fight against corruption means supporting transparency and independent control of political parties, cautious investigation of suspicions of public entities misusing their position and illegal financing of political parties, fight against corruption and growing clientelism by legislative regulation for public procurement, preservation of ethical principles and performance supporting moral improvement of the society.

Corruption is very often associated with the term lobbying and these two terms are often reversed. Lobbying can be characterised as direct impact of an individual, a common group, or a group's member on an elected representative/employee of the public sector. Its goal is to influence the result of legislation or regulation process and it neither represents common interest nor corruption. Unlike corruption, lobbying is significant for its activity that is public or controllable. These influential activities should be accessible by all interested parties.

\section{C.Increase of Law Justification and Quality of Legislation}

It is essential to increase enforcement of the law and to substantially shorten the duration of the legal proceedings, to increase the demands on the value orientation of the judges, to ensure the stability and exactness of legislative regulations, to adopt a system of evaluation of the regulations passed, to exclude indirect and non-systematic amendments of the regulations.

The enforcement of the law is one of the basic pillars of democracy, healthy economy and development of the society. Despite this well-known fact, the reality is far from ideal. It is very dangerous to issue an invoice, as the number of those who decide not to settle their invoices has been growing continuously, as they follow numerous examples that suffered no penalties. Slovakia is ranked as 140 out of 144 countries (Asociácia zamestnávatel'ských zväzov a združení, 2013).

\section{Decrease of Tax Charge and Effective Social System}

Long-term problems of the social system of Slovakia directly arise from the main deformations of public finances - the extensive position and activities of the government towards the economy and the society. Public finances are also related to the budget deficit. In Slovakia, the level of general government deficit in 2010 was $7.8 \%$ of GDP, in $2011-4.9 \%$ and in $2012-4.6 \%$ of GDP. The deficit of public finances was reduced by various regulatory measures aimed at increasing taxes (Víghová, 2010). More than half of the Slovak citizens are customers of the public social system that provides various social benefits and services out of taxes, also to those people who do not need them (in terms of their income). The social system is also very complicated - it contains over 70 types of social assistance, and yet there is a large group of people in need who cannot be assisted by this system. 
The common problem of the social system is the extensive role of the government and a sort of addiction of the people to social assistance- they get used to getting money from the public sector. The obvious example of this is in the pensions sector, which is not sustainable in its current form, considering the ageing population.

The demographic development is not only going to ruin pension budgets - the healthcare costs will increase, including long-term care for the elderly citizens. The government needs to address the following problems as priorities (Gonda, Durana, Mlýnek, 2010):

Extensive and non-addressing social solidarity by the government, causing addiction to the social system;

- Costly and ineffective social system with high levies;

- Constraints and inadequate motivating conditions towards self-support, voluntary solidarity, private activities of the clients and competitiveness of the providers of social services.

\section{E. Improving the Quality of Education}

Improving the education system by applying the methods used by other successful countries (including the materials and instruments), providing information to the public about the quality of schools and possibilities of employment of graduates, empowering the competitiveness among colleges and universities on the national and international scale, and creation of conditions for effective cooperation between educational institutions and the entrepreneurial sector - these are the tasks that need to be addressed.

\section{F. Reformation of Existing Departments and Public Institutions}

It is necessary to simplify and digitalise communication with public offices, to shorten waiting periods, to merge the database systems of different offices, which can lead to flexible, fast and effective public administration and create conditions that can constrain subjective decision-making on any official permission. It can also provide space to apply the maximum lengths for permissions, which can stabilise the entrepreneurial sector.

\section{G.Transparency of Public Spending}

Providing the public with clear information about public spending and the activities of public institutions, enforce independent control of economic effectiveness, communicating with the public about the usage of the EU funds, enlarging the competence of the government to control local governments - the basic goal of the public spending is to provide public demands. Public finances are allocated to the public budgets to activate the fiscal functions of the state (or government, local government, municipalities, etc.), based on the principles of non-payoff and non-equivalency.

Although a feedback exists in the form of taxes, consumers of the public demands and activities tend to overspend public resources, and therefore spending increases. The transfers can be de-motivating and causing addiction, just as in the case of the social system. There are many factors, however, that cause this increase:

the structure of the state activities - it comes from historical, cultural, ethical and other functions of the state;

objective causes; 
- geographic factors, such as natural disasters;

- demographic factors, such as healthcare, educational system, social care, etc;

- urbanistic factors, such as development of the infrastructure, services, etc;

- technical and technological factors, such as the need of state aid by applying important innovations and discoveries;

- outcome shocks - they can be natural in character, as well as social, political instabilities and changes, increased bureaucracy and its ineffectiveness, etc.;

- demonstration effect - if in the result of the influence from other regions and countries, the citizens put pressure on the local and national authorities to provide certain amount of financial resources in the form of a public service;

- fiscal illusion - public ignorance of the fact that increasing public services will lead to increased public spending, and this can lead to overspending and ineffectiveness.

\section{H. Defence of Honest Businessmen against Unfair Practices of Business Partners}

In the entrepreneurial environment, there is a need to consistently fight against cheating. It is the main concern to protect honest citizens by creating the black list of dodgers and persons convicted of economic offences. The sanctions must be increased, including the ban onbusiness activity. The professional and material preparation of the investigators and

\section{Perception of Entrepreneurs as Partners in terms of Economic Development}

The entrepreneurs need to be taken into account in policy-making, public performance and structure of the economy. This needs to happen regularly in the area of creating job opportunities, public budgets and overall development of the economy and enhancement of the living standards and living conditions of the population.

\section{J. Compliance with the Obligations and Regulations of the EU}

The European Monetary Union requires compliance with the obligations and being a responsible Member State of the $\mathrm{EU}$ as well as supporting and joining the other countries of the EU that require compliance with the rules equally for all the Member States.

\section{Conclusions}

The problems and dangers of the entrepreneurial conditions in the current highly dynamic business environment bring higher or lower risk possibilities. It is no news that every human activity, private or business, is risky and can lead towards critical situations. Crisis management is a modern term in business. Companies need to become more competent and educated to have certain proceedings in place in order to manage the crisis.

The decision-making processes in small and medium-sized enterprises are subject to trends and innovations, just as any other processes and technologies. Their quality is determined by the strength and position of the business entity, the person making the 
decision, the information basis used during the process, the timeline and the impact of decisions, the ability to create alternatives and judge on the decision-making criteria. The changes of the decision-making process are visible in particular as the result of the pressure of the economic crisis, and the reaction of the entrepreneurs to globalisation, instability of the economic and political environment, evolution of the business and competition environment (Kajanová, 2012).

The list of negative circumstances is not exhaustive, and governmental interference can either help constraining them or turning into some of them. The Slovak Republic and its economy need stability and clarity in order to assist all the business enterprises in overcoming the financial and economic crisis, for which some of the possible steps are provided in this article. However, the decisions are purely political, therefore we cannot forecast the future development of the entrepreneurial environment outright.

\section{Acknowledgments}

The contribution was written within the research project VEGA 1/1109/12 on 'Indicators for evaluation of the proprietary, financial and income situation of business entities in globalisation conditions'.

\section{References}

1. Asociácia zamestnávatel’ských zväzov a združení. (2012, Nov 15). Podnikatelia: Ficove zmeny zhoršili prostredie pre biznis. Hnoline.sk. Accessed on 16 November 2012, http://www.azzz.sk/doc/monitoring/azzz_export_16.11.doc.

2. Asociácia zamestnávatel’ských zväzov a združení. (2013, Jan 17). Štát pripravuje pre podnikatel'ov portál proti byrokracii. Pravda.sk. Accessed on 22 February 2013, www.azzz.sk/doc/monitoring/azzz_export_18.01.2013.doc.

3. Butoracová Šindleryová, I., Morovská, I. (2009). Entrepreneurship Environment in the Slovak Republic from the Point of Regional Innovation, Perspectives and Development Limits. In: Kotulic, R. (ed.) Zborník vedeckých prác katedry ekonómie a ekonomiky ANNO 2009. Prešovská univerzita v Prešove. Accessed on 20 February 2013, www.pulib.sk/elpub2/FM/Kotulic10/pdf_doc/5.pdf.

4. Drury, C. (2009). Management accounting for business. 4th edition. China: RR Donnelley.

5. Gonda, P., Ďurana, R., Mlýnek, M. (2010). Sociálny systém. Reformnavlada.sk. Accessed on 22 February 2013, http://www.reformnavlada.sk/socialny-system.html.

6. Kajanová, J. (2011). The Competitive Advantage in the Global Labour Market. In: Business, Management and Education, Vol. 9, No. 2 (157 - 170).

7. Kajanová, J. (2012). Tendencie v rozhodovaní malých a stredných podnikov v aktuálnych podmienkach podnikatel’ského prostredia. In Podniková ekonomika a manažment. ISSN 13365878 
8. Klamová, S. (2010, March 3). Slovenskí podnikatelia v EÚ. Accessed on 25 February 2013, http://www.sav.sk/?lang=sk\&charset=\&doc=services-news\&news_no=3138.

9. Kováč, M. (2011). Public Security as a factor of Socio-Economic Development and its Measurement. In: Ekonomični nauki, Vol. II, no. 42, č. 2, t. 2, p. 360-365.

10. Majdúchová, H., Neumannová, A. (2008). Podnikové hospodárstvo pre manažérov. Bratislava: IURA EDITION.

11. Mihóková, L. (2012). Vývoj fiškálnej nerovnováhy a jej prehlbovanie v kontexte ekonomickej krízy. In: Finančné trhy - Odborný mesačník pre teóriu a prax finančných trhov. Vol. 9, April 2012. Accessed on 25 February 2013, www.derivat.sk/files/casopis\%202012/2012_Apr_Mihokova.pdf.

12. Ministry of Foreign Affairs of Slovak Republic (2007). Proexportná politika Slovenskej republiky na roky 2007 - 2013. Accessed on 20 February 2013, http:// www.mzv.sk/App/wcm/media.nsf/vw_ByID/ID_2CC5A44537350E77C125767400 24615A_SK/\$File/proexportna_politikaSR_\%202007_2013.pdf

13. Ölvecká, V. (2010). Náklady vo finančnom riadení. 1st edition. Bratislava: KARTPRINT.

14. Podnikatel'ská aliancia Slovenska. (2012, Nov 15). Zhoršovanie podnikatel'ského prostredia sa zrýchluje. Accessed on 16 November 2012, http://alianciapas.sk/category/pravidelne_aktivity/index_podnikatelskeho_prostredia/.

15. Podnikatel'ská aliancia Slovenska. (2012, Feb 1). Wish list 2012. Accessed on 22 February 2013, http://alianciapas.sk/tag/podnikatelske-prostredie/page/2/.

16. Remišová, A. (1999). Podnikatel'ská etika v praxi - cesta k úspechu. Bratislava: EPOS.

17. Rentková, K., Rentková A. (2012). Vvybrané zmeny v Zákonníku práce a ich vplyv na podnikatel'ské prostredie na Slovensku (The selected changes in Labor Code and their influence on the business environment on the business environment within the Slovakia (Brief overview and characteristic)). In: Horizonty podnikatel'ského prostredia. Bratislava: Univerzita Komenského. ISBN 978-80-223-3347-4

18. Stoličná, Z. (2012). Dlhová kríza a protikrízové opatrenia. In Zborník recenzovaných príspevkov . Bratislava: Ekonomická univerzita, p. 1-8. ISBN 978-80-970244-5-1

19. Tucker, I. (2008). Economics for Today's World. Fifth Edition. Beauceville: Transcontinental.

20. Víghová, A. (2010). Stav verejných financií a cesty úspornosti na ich ozdravenie. In: Ekonomický a sociálny rozvoj Slovenska. Komunálna reforma - spravovanie a manažovanie - trendy vo verejnom živote - regionálny rozvoj. Zborník príspevkov z medzinárodnej vedeckej konferencie, Bratislava 25 Novembra 2010, Bratislava : crr.sk, s. 737, ISBN : 978-80-970495-4-6. 


\section{ENTREPRENERYSTĖS APLINKOS SLOVAKIJOJE RAIDA}

Santrauka. Entreprenerystès aplinka Slovakijoje yra nuolat matuojama ir šiuo metu pastebimos blogejimo tendencijos. Entrepreneriai patys pripažįsta situacijos blogejjimą bei tai patvirtina regioninių ir nacionalinių agentūrų pateikti duomenys. Slovakijos Respublikoje mažos ir vidutinès ịmonès vaidina labai svarbų vaidmenị. Entrepreneriai pripažįsta mokesčių didejjimą, dažnus ịstatymų kaitaliojimus, sunkią teisètvarkos būklę, paskolų trūkumą, ambicingas nepagrịstas politikas, korupciją ir kt. kaip pačias didžiausias kliūtis entreprenerystès plètrai Slovakijoje. Šių problemų apibrèžimas ir sprendimas yra labai svarbus, siekiant paskatinti smulkiojo ir vidutinio verslo plètrą. Tai leistų ne tik pagerinti entreprenerystės sąlygas bet ir padidinti Slovakijos konkurencingumą.

Straipsnio tikslas yra apibrěžti entreprenerystès ir verslo sąlygas Slovakijoje, turinčias ịtakos smulkių ir vidutinių įmonių steigimui, kuris garantuoja naujų darbo vietų kūrimą ir regioninę plètrą.

Viera ÖLVECKÁ - PhD., Department of Economics and Finances, Faculty of Management of the Comenius University in Bratislava, Slovakia. Research fields: financial management, accounting, risk management.

Viera ÖLVECKÁ - Comenius universiteto Vadybos fakulteto Ekonomikos ir finansų katedra, mokslų daktarè. Mokslinių tyrimų sritys: finansų valdymas, apskaita, rizikos valdymas. 